\title{
N-N-Dimethylformamide concentration in environmental and alveolar air in an artificial leather factory
}

\author{
F BRUGNONE, L PERBELLINI, AND E GAFFURI \\ From the Institute of Occupational Medicine, University of Padua-Verona, Italy
}

ABSTRACT N-N-Dimethylformamide was determined every hour during the eight hours of the work shift in the alveolar air of eight workers employed in an artificial leather factory and in the breathing zone of the eight workers. The alveolar ventilation of each worker was measured for 10 minutes during the work shift. Alveolar dimethylformamide concentration (Ca) was correlated with the environmental concentration $(\mathrm{Ci})$ in six of the eight workers. The amount of dimethylformamide retained per litre of ventilated air, calculated as the difference $(\mathrm{Ci}-\mathrm{Ca})$, was correlated with environmental concentration in seven of the eight workers. Lung uptake of dimethylformamide per minute was correlated with environmental concentration in all eight workers. The ratios between alveolar and environmental concentration $(\mathrm{Ca} / \mathrm{Ci} \times 100)$ and the lung retention of dimethylformamide, calculated by the formula $(1-\mathrm{Ca} / \mathrm{Ci}) \times 100$, were $27.8 \%$ and $72.2 \%$ respectively. They did not show any correlation with environmental concentration, exposure time, or alveolar ventilation.

$\mathrm{N}-\mathrm{N}$-Dimethylformamide (DMF) is widely used as an industrial solvent in various manufacturing processes. Although hepatotoxic effects have been described by several workers ${ }^{1-5}$ the retention and uptake of DMF by the lung has never been studied.

The aim of the present study was to investigate the relationship between alveolar and environmental concentration of DMF and, if possible, to quantify the lung uptake in workers occupationally exposed under industrial conditions.

\section{Materials and methods}

Eight workers employed in an artificial leather factory were examined, and from each alveolar air samples were obtained. In addition, eight samples of environmental air were taken for each worker. Samples were taken at every hour from 0900 to 1700 , except during lunch time, which was from 1200 to 1300 .

A total of 64 double air samples were taken. Alveolar air samples were collected in stoppered

Requests for reprints to: Professor F Brugnone, Istituto di Medicina del Lavoro, Policlinico BorgoRoma, 37100-Verona.

Received 11 November 1978

Accepted 16 July 1979 glass tubes with screw caps at both ends, with an inside volume of $70 \mathrm{ml}$. After half a minute of apnoea workers gave a forced expiration, keeping the glass tube between their lips. The tube was immediately sealed by the two caps after the end of the expiration. ${ }^{6}$ Environmental air samples were taken from the breathing zone of each worker at the place he was during the alveolar air sampling. Environmental samples were collected into similar glass tubes used for the alveolar air by means of a manual pump. The plant was a shed measuring $118 \times 20 \times 5 \mathrm{~m}$. The manufacturing processes of the factory consisted of three different stages: $(a)$ preparing paint to add to and mix with a solution of polyurethane in DMF made elsewhere; $(b)$ smearing the coloured polyurethane solution on to a cotton cloth or other textile cloth with a machine; and (c) checking the finished product. There was no division in the shed among the three different stages, and workers could move about from place to place. Two workers prepared and mixed the paints and one checked the finished product; the remaining five workers looked after the smearing machine.

There was no evidence of skin absorption of DMF during the work shift in any of the workers. They wore gloves of plastic material to avoid skin contact with the polyurethane solution, and their work clothes were not wetted or sprinkled with 185 
Dimethylformamide concentration $\left(\mathrm{mg} / \mathrm{m}^{3}\right)$ in environmental $(\mathrm{C} i)$ and alveolar $(\mathrm{Ca})$ air and alveolar ventilation $(\dot{V} A)$

\begin{tabular}{|c|c|c|c|c|c|c|c|c|c|c|c|c|}
\hline \multirow[t]{2}{*}{ Subject No } & \multirow[t]{2}{*}{$\dot{V} A l, m$} & & \multicolumn{8}{|c|}{ Sampling time $(h)$} & \multirow[t]{2}{*}{$\bar{M}$} & \multirow[t]{2}{*}{$S D$} \\
\hline & & & 9 & 10 & 11 & 12 & 14 & 15 & 16 & 17 & & \\
\hline 1 & $14 \cdot 2$ & $\begin{array}{l}\mathrm{Ci} \\
\mathrm{Ca}\end{array}$ & $\begin{array}{l}3 \cdot 1 \\
0 \cdot 9\end{array}$ & $\begin{array}{l}8 \cdot 0 \\
1 \cdot 3\end{array}$ & $\begin{array}{l}5.0 \\
1.0\end{array}$ & $\begin{array}{l}6 \cdot 2 \\
0.9\end{array}$ & $\begin{array}{l}6 \cdot 4 \\
1 \cdot 3\end{array}$ & $\begin{array}{l}5 \cdot 6 \\
2 \cdot 4\end{array}$ & $\begin{array}{l}9 \cdot 3 \\
1 \cdot 8\end{array}$ & $\begin{array}{l}5 \cdot 3 \\
1 \cdot 8\end{array}$ & $\begin{array}{l}6 \cdot 1 \\
1 \cdot 4\end{array}$ & $\begin{array}{l}1.9 \\
0.5\end{array}$ \\
\hline 2 & $16 \cdot 0$ & $\begin{array}{l}\mathrm{Ci} \\
\mathrm{Ca}\end{array}$ & $\begin{array}{r}12 \cdot 0 \\
2 \cdot 9\end{array}$ & $\begin{array}{l}5 \cdot 3 \\
2 \cdot 0\end{array}$ & $\begin{array}{l}2 \cdot 0 \\
0 \cdot 4\end{array}$ & $\begin{array}{l}2.4 \\
0.9\end{array}$ & $\begin{array}{l}6.4 \\
1.8\end{array}$ & $\begin{array}{l}3 \cdot 5 \\
1 \cdot 4\end{array}$ & $\begin{array}{l}6 \cdot 4 \\
1 \cdot 1\end{array}$ & $\begin{array}{l}6.4 \\
2.9\end{array}$ & $\begin{array}{l}5 \cdot 5 \\
1 \cdot 7\end{array}$ & $\begin{array}{l}3 \cdot 2 \\
0 \cdot 9\end{array}$ \\
\hline 3 & $9 \cdot 3$ & $\begin{array}{l}\mathrm{Ci} \\
\mathrm{Ca}\end{array}$ & $\begin{array}{l}5 \cdot 3 \\
2 \cdot 4\end{array}$ & $\begin{array}{l}5 \cdot 3 \\
1 \cdot 8\end{array}$ & $\begin{array}{l}7 \cdot 8 \\
2 \cdot 4\end{array}$ & $\begin{array}{r}11 \cdot 8 \\
2 \cdot 2\end{array}$ & $\begin{array}{r}24 \cdot 2 \\
5 \cdot 1\end{array}$ & $\begin{array}{l}9 \cdot 5 \\
2 \cdot 4\end{array}$ & $\begin{array}{l}1.8 \\
-\end{array}$ & $\begin{array}{l}1 \cdot 1 \\
-\end{array}$ & $\begin{array}{l}8 \cdot 3 \\
2 \cdot 0\end{array}$ & $\begin{array}{l}7 \cdot 3 \\
1 \cdot 6\end{array}$ \\
\hline 4 & $10 \cdot 1$ & $\begin{array}{l}\mathrm{Ci} \\
\mathrm{Ca}\end{array}$ & $\begin{array}{l}3 \cdot 9 \\
1 \cdot 8\end{array}$ & $\begin{array}{l}4 \cdot 0 \\
1 \cdot 1\end{array}$ & $\begin{array}{l}8.9 \\
2.0\end{array}$ & $\begin{array}{l}6 \cdot 0 \\
2 \cdot 9\end{array}$ & $\begin{array}{r}11.5 \\
3.8\end{array}$ & $\begin{array}{r}12.6 \\
4.0\end{array}$ & $-^{1.8}$ & $\begin{array}{l}2 \cdot 4 \\
-\end{array}$ & $\begin{array}{l}6.4 \\
1.9\end{array}$ & $\begin{array}{l}4 \cdot 1 \\
1 \cdot 5\end{array}$ \\
\hline 5 & $12 \cdot 4$ & $\begin{array}{l}\mathrm{Ci} \\
\mathrm{Ca}\end{array}$ & $\begin{array}{l}1 \cdot 8 \\
-\end{array}$ & $\begin{array}{l}2 \cdot 0 \\
0.4\end{array}$ & $\begin{array}{l}1 \cdot 5 \\
-\end{array}$ & $\begin{array}{l}2 \cdot C \\
0 \cdot 4\end{array}$ & $\begin{array}{l}2.4 \\
0.7\end{array}$ & $L^{1 \cdot 1}$ & $\begin{array}{l}2.4 \\
0.9\end{array}$ & $\begin{array}{l}2.2 \\
0.7\end{array}$ & $\begin{array}{l}1.9 \\
0.4\end{array}$ & $\begin{array}{l}0.4 \\
0.4\end{array}$ \\
\hline 7 & $8 \cdot 3$ & $\begin{array}{l}\mathrm{Ci} \\
\mathrm{Ca}\end{array}$ & $\begin{array}{l}3.5 \\
0.7\end{array}$ & $\begin{array}{l}4 \cdot 0 \\
0 \cdot 9\end{array}$ & $\begin{array}{l}7 \cdot 5 \\
2 \cdot 0\end{array}$ & $\begin{array}{l}4 \cdot 7 \\
1 \cdot 8\end{array}$ & $\begin{array}{l}4 \cdot 4 \\
1 \cdot 8\end{array}$ & $\begin{array}{l}3 \cdot 7 \\
1 \cdot 8\end{array}$ & $\begin{array}{r}20 \cdot 9 \\
7 \cdot 1\end{array}$ & $\begin{array}{l}9 \cdot 1 \\
4 \cdot 4\end{array}$ & $\begin{array}{l}7 \cdot 2 \\
2 \cdot 5\end{array}$ & $\begin{array}{l}5 \cdot 9 \\
2 \cdot 1\end{array}$ \\
\hline 8 & $10 \cdot 6$ & $\begin{array}{l}\mathrm{Ci} \\
\mathrm{Ca}\end{array}$ & $\begin{array}{l}2 \cdot 7 \\
-\end{array}$ & $\begin{array}{l}2 \cdot 2 \\
0.9\end{array}$ & $\begin{array}{l}4 \cdot 4 \\
0 \cdot 4\end{array}$ & $\begin{array}{l}4 \cdot 9 \\
2 \cdot 2\end{array}$ & $\begin{array}{l}4 \cdot 4 \\
2 \cdot 0\end{array}$ & $\begin{array}{l}3 \cdot 1 \\
1 \cdot 8\end{array}$ & $\begin{array}{r}10 \cdot 6 \\
4 \cdot 0\end{array}$ & $\begin{array}{l}4 \cdot 7 \\
2 \cdot 4\end{array}$ & $\begin{array}{l}4 \cdot 6 \\
1 \cdot 7\end{array}$ & $\begin{array}{l}2 \cdot 6 \\
1 \cdot 3\end{array}$ \\
\hline $\mathrm{Ci}$ & & $\begin{array}{l}\overline{\mathbf{M}} \\
\mathrm{SD}\end{array}$ & $\begin{array}{l}4 \cdot 3 \\
3 \cdot 3\end{array}$ & $\begin{array}{l}4 \cdot 2 \\
2 \cdot 0\end{array}$ & $\begin{array}{l}4 \cdot 8 \\
3.0\end{array}$ & $\begin{array}{l}5 \cdot 1 \\
3 \cdot 1\end{array}$ & $\begin{array}{l}7 \cdot 9 \\
7 \cdot 1\end{array}$ & $\begin{array}{l}5 \cdot 2 \\
3 \cdot 9\end{array}$ & $\begin{array}{l}6.9 \\
6 \cdot 7\end{array}$ & $\begin{array}{l}4 \cdot 1 \\
2 \cdot 8\end{array}$ & & \\
\hline
\end{tabular}

solvent. Alveolar ventilation ( $\dot{\mathrm{V} A})$ of the workers was measured for $10 \mathrm{~min}$, the workers breathing through a mask equipped with a volumetric meter (Wright respirometer type PM British Oxygen). Respiratory dead-space was valued at $30 \%$. All air samples were kept at a temperature of $37^{\circ} \mathrm{C}$ and tested by Perkin-Elmer mod F 17 gas-chromatograph with FID; column: $2 \mathrm{~m} \times 3 \mathrm{~mm}$ outside diameter steel column, packed with Carbowax $15000.2 \%$, on Carbopack C 80-100 mesh; temperatures: injector and detector $225^{\circ} \mathrm{C}$, oven $145^{\circ} \mathrm{C}$; carrier gas: nitrogen; flow rate: $30 \mathrm{ml} / \mathrm{min}$. Other details of the materials and methods are given elsewhere. ${ }^{7} 8$

\section{Results}

The table shows the results of DMF determination in environmental and alveolar air. Figure 1 makes it clear that the concentration of DMF in the environmental air was unstable, with peak values arising by chance in any work place and at any time during the work shift. The alveolar concentration of DMF (Ca) correlated well with environmental concentration (Ci) at any moment, but was always lower (fig 1). The alveolar concentration of DMF was correlated with environmental concentration in six of the eight workers tested. The amount of DMF retained per litre of ventilated air, calculated as the difference between environmental and alveolar concentration $(\mathrm{Ci}-\mathrm{Ca})$, was correlated with the environmental concentration of DMF in seven of the eight workers.
The two workers who showed no correlation between $\mathrm{Ci}$ and $\mathrm{Ca}$ showed a correlation between $(\mathrm{Ci}-\mathrm{Ca})$ and $\mathrm{Ci}$. On the other hand, the only worker who showed no correlation between $(\mathrm{Ci}-\mathrm{Ca})$ and $\mathrm{Ci}$ did show a correlation between $\mathrm{Ci}$ and $\mathrm{Ca}$. The mean percentage of DMF retained for the eight workers tested was in the range $64 \cdot 1-82.7$ as calculated from the formula:

$$
\text { Retention \% }(\mathrm{R})=(1-\mathrm{Ca} / \mathrm{Ci}) \times 100 .
$$

The lung retention ranges were not correlated with environmental concentration of DMF, nor with exposure time or with alveolar ventilation.

Lung uptake was calculated from the formula: $(\mathrm{Ci}-\mathrm{Ca}) \times \dot{\mathrm{V} A}$, and ranged between 17.9 and $67 \cdot 1$ $\mu \mathrm{g} / \mathrm{min}$ in the eight workers tested. A good correlation was found between lung uptake and environ-
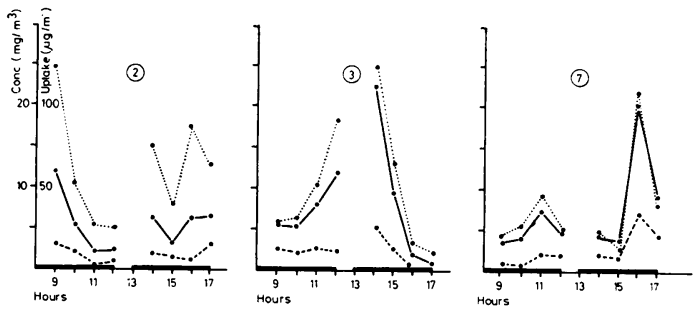

Fig 1 Environmental concentration (-), alveolar concentration (- - $)$ ) and lung uptake $(. . .$.$) of$ DMF during the work shift in workers 2,3 , and 7. 


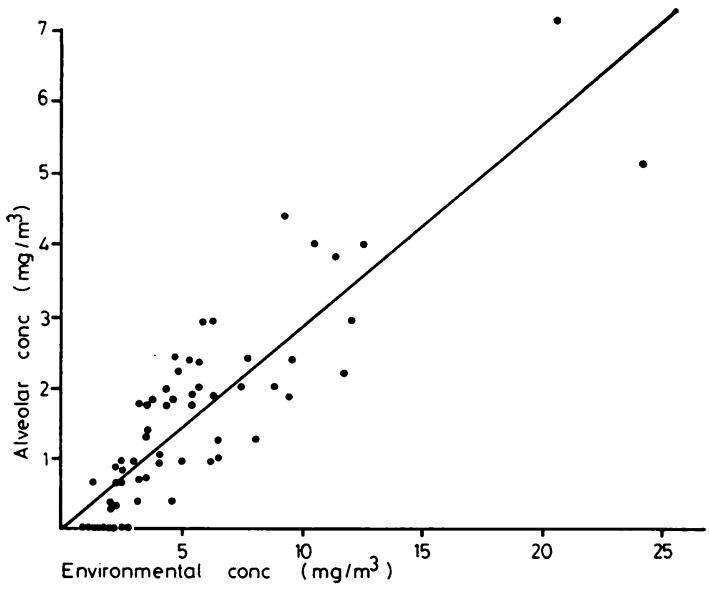

Fig 2 Relation between alveolar and environmental concentration of DMF $(y=0.278 \times+0.06$; $r=0.8733 ; n=64 ; p<0.001)$.

mental concentration of DMF in all eight workers. The data from the eight tests on each worker were pooled, and it was found that alveolar concentration, the amount of DMF retained $(\mathrm{Ci}-\mathrm{Ca})$, and the lung uptake per minute turned out to be highly correlated with the environmental concentration of DMF (figs 2-4).

\section{Discussion}

The exchange of gases between the body and the environment results from several processes which

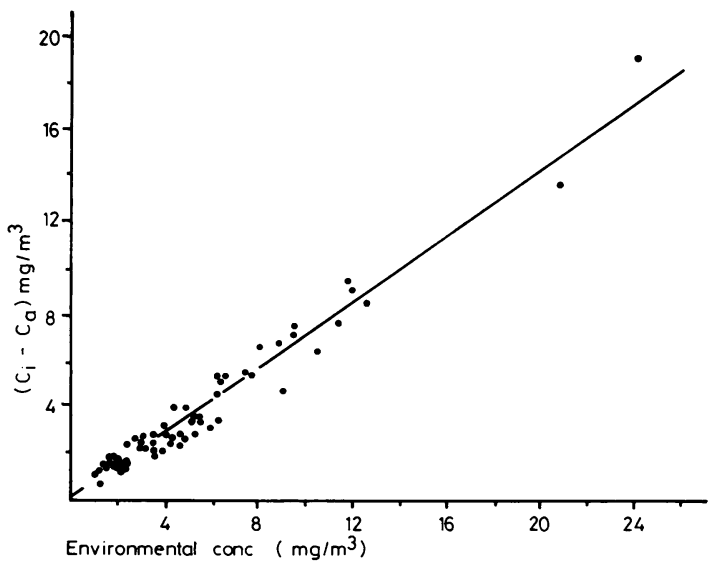

Fig 3 Relation between amount of DMF retained $(\mathrm{Ci}-\mathrm{Ca})$ and environmental concentration of DMF $(y=0.722 \times-0.06 ; r=0.9777 ; n=64 ; p<0.001)$.

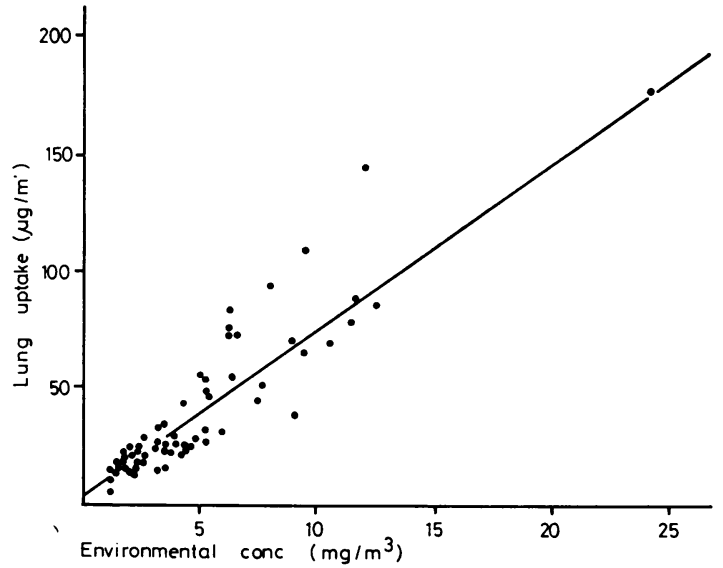

Fig 4 Relation between lung uptake and environmental concentration of DMF $(y=7.0 \times+4.9 ; r=0.8956$; $n=64 ; p<0.001)$.

include the ventilation of the lungs; the exchange of gas between the lungs and the blood; and the circulation of the blood between the lungs and the other tissues where further exchange of gas takes place. The alveolar concentration of DMF in our study, apart from the other processes, is the result of its exchange between the alveoli and the blood in the alveolar capillary membrane. From the above remarks it emerges that the lung retention of DMF calculated by the formula $(1-\mathrm{Ca} / \mathrm{Ci}) \times 100$ is the retention of the alveoli and not of the whole respiratory tract, which is given by the formula $(1-\mathrm{Ce} / \mathrm{Ci})$ $\times 100$, where $\mathrm{Ce}$ is the concentration in the expired air. For the same reason, moreover, the lung uptake calculated by the formula $(\mathrm{Ci}-\mathrm{Ca}) \times \dot{\mathrm{VA}}$ is the absorption of the alveoli and not of the whole respiratory tract, which is given by $(\mathrm{Ci}-\mathrm{Ce}) \times \dot{\mathrm{VE}}$, where $\dot{V} E$ is the total ventilation.

Our data show that the best correlation was between the retained amount and environmental concentration ( $r=0.9777$ ) (fig 3 ).

The slope of the regression line in figs 2 and 3 shows that the alveolar concentration of DMF was $27.8 \%$ of the environmental concentration and the lung retention $72 \cdot 2 \%$.

Even though the correlation between lung uptake and environmental concentration (fig 4) remains significant $(\mathrm{p}<0.001)$, its correlation coefficient is lower $(r=0.8956)$ than that between $(\mathrm{Ci}-\mathrm{Ca})$ and $\mathrm{Ci}$ in fig $3(\mathrm{r}=0.9777)$. It seems clear from this that the lowering of the correlation coefficient in fig 4 is due to the $\dot{V} A$ which ranged between $8 \cdot 3$ and $16 \mathrm{l} / \mathrm{min}$ among the eight workers tested (table). The above observation seems to suggest that the lung 
uptake of DMF in workers exposed during light work can be directly calculated from lung retention, taking into account the individual value of $\dot{V A}$.

\section{Conclusion}

Our research has shown that environmental concentration of DMF changed considerably during the work shift and from one work place to another. Despite this unpredictable variability, the concentration of DMF in the alveolar air of the eight workers always unambiguously reflected the environmental concentration of DMF of the respective work places.

In our previous papers, which dealt with almost steady acetone exposure and with progressively increasing exposure to n-hexane and its isomers, ${ }^{910}$ similar results were found. In our opinion all these results, which are very unlikely to be coincidental, indicate that the alveolar air of exposed workers might represent the most reliable means of evaluating individual solvent exposure, apart from the practical difficulty of the number of alveolar samples to be taken for every single worker. This statement is especially valid in the case of industrial workers whose $\dot{V A}$ is not very high since it relates to work which is generally light.

We thank Miss $\mathbf{P}$ Morgan for supervising our English.

\section{References}

${ }^{1}$ Tolot F, Droin J, Genevois M. Intoxication par la dimethylformamide. Arch Malad Profession 1958; 19:602.

${ }^{2}$ Martelli B. Tossicologia della dimetilformamide. Med Lav 1960;51:123.

${ }^{3}$ Reinl W, Urban HJ. Erkrankungen durch Dimethylformamid. Archiv Gewerbepathol Gewerbehhygiene 1965; $21: 333$.

${ }^{4}$ Finzel L. Zur Klinischen symptomatologie nach erhohter Dimethylformamideinwirkung am Arbeitsplatz. Arbeitsmed Sozialmed Arbeitshyg 1972:356.

${ }^{5}$ Perbellini L, Costa G, Faggionato G, Carnevale F, D'Andrea F. Patologia professionale da Dimetilformamide. Folia Med 1973;7/8:323-38.

${ }^{6}$ Stewart RD. The use of breath analysis in clinical toxicology. In: Wayland I, Hayes J, eds. Essay in toxicology. New York-London: Academic Press, 1974:121-47.

${ }^{7}$ Brugnone F, Perbellini L, Grigolini L, Cazzadori A, Gaffuri E. Alveolar air and blood toluene concentration in rotogravure workers. Int Arch Occup Environ Health 1976;38:45-54.

${ }^{8}$ Perbellini L, Brugnone F, Grigolini L, Cunegatti P, Tacconi A. Alveolar air and blood dichloromethane concentration in sole factory workers. Int Arch Occup Environ Health 1977;40:241-7.

${ }^{9}$ Brugnone F, Perbellini L, Grigolini L, Apostoli P. Solvent exposure in a shoe upper factory: I. n-Hexane and acetone concentration in alveolar and environmental air and blood. Int Arch Occup Environ Health 1978; 42:51-62.

${ }^{10}$ Brugnone F, Perbellini L, Grigolini L, Apostoli P. Solvent exposure in a shoe upper factory: II. Methylcyclopentane, 2-methylpentane and 3-methylpentane concentration in alveolar and environmental air and blood. Int Arch Occup Environ Health 1979;42:355-63. 